\title{
ISOLATION AND CHARACTERISATION OF AN ETHYLENE RECEPTOR (ERS-TYPE) FROM OIL PALM (Elaeis guineensis Jacq.) MESOCARP
}

\author{
NURNIWALIS, A $W^{\star}$; ZUBAIDAH, $\mathbf{R}^{\star}$; SITI NOR AKMAR, $A^{* *}$; SUHAIMI, $\mathbf{N}^{\ddagger}$ and MASSAWE, $\mathrm{F}^{\ddagger \ddagger}$
}

\begin{abstract}
The oil palm (Elaeis guineensis Jacq.) fruit is climacteric whereby ripening process of the fruits is accompanied by a burst of ethylene production. Hence, to understand the underlying molecular mechanisms and the role of ethylene in the ripening process of oil palm fruits, this study focused on the isolation and characterisation of the ethylene receptor gene, the first component in the ethylene signalling pathway. The full-length cDNA is $2225 \mathrm{~kb}$ long and encodes a polypeptide of 629 amino acid residues. Sequence analysis showed it has conserved domains and a protein structure similar to the ERS-type ethylene receptors found in ethylene receptor genes from other plant species. Northern and Southern analyses revealed that it is highly expressed in the mesocarp tissues and that this gene exists as multiple copies in the oil palm genome. These results provide evidence that oil palm fruit development is regulated by ethylene through the action of the EGER D3 ethylene receptor gene, which opens up the possibility of manipulating the ethylene receptor to control ethylene sensitivity during oil palm fruit development to help further improve oil palm yields.
\end{abstract}

\section{Keywords: ethylene receptor, oil palm, fruit, mesocarp, ethylene signaling, ripening}

Date received: 16 October 2017; Sent for revision: 19 October 2017; Received in final form: 24 November 2017; Accepted: 5 February 2018.

\section{INTRODUCTION}

Ethylene is widely known to regulate many aspects of plant growth and developmental processes. Among the prominent roles include seed germination, root and stem elongation, flower senescence, abscission, sex determination as well as fruit ripening especially in climacteric

\footnotetext{
* Malaysian Palm Oil Board,

6 Persiaran Institusi,

Bandar Baru Bangi, 43000 Kajang,

Selangor, Malaysia.

E-mail: nurni@mpob.gov.my

** Faculty of Agriculture and Institute of Tropical Agriculture, Universiti Putra Malaysia, 43400 UPM Serdang, Selangor, Malaysia.

‡ Faculty of Biotechnology and Biomolecule Science, Universiti Putra Malaysia, 43400 UPM Serdang, Selangor, Malaysia.

抹 School of Biosciences, The University of Nottingham Malaysia Campus, Jalan Broga, 43500 Semenyih, Selangor, Malaysia.
}

fruits (Abeles et al., 1992). The ripening process especially in fleshy fruits involves a wide range of biochemical, physiological and molecular changes that affect the appearance, colour, texture, flavour and aroma of the fruit and as a result, the ripe fruit becomes more attractive, desirable and palatable for consumption (Bouzayen et al., 2010). Apart from ethylene, multiple hormones including abscisic acid, auxin, gibberellin, cytokinin, as well as brassinosteroid are also known to be involved in the development and ripening process in fruits (McAtee et al., 2013).

Physiological and biochemical changes that accompany the development of oil palm fruits until they ripen have been widely reported and reviewed (Sambanthamurthi et al., 2000; Corley and Thinker, 2016; Nurniwalis, 2017). However, it is surprising that for an important crop such as the oil palm, fruit development especially hormonal control of fruit development, has not 
received much attention (Sambanthamurthi et al., 2000; Corley and Thinker, 2016; Nurniwalis, 2017). Hormonal changes during early fruit development and maturation through to ripening of oil palm fruits have been recently described (Tranbarger et al., 2011; Teh et al., 2014). Five major phytohormones namely, auxin, gibberellin, cytokinins, abscisic acid and ethylene are involved in the development of oil palm fruits mesocarp (Tranbarger et al., 2011; Teh et al., 2014).

Several studies have demonstrated the role of ethylene in promoting the ripening process of oil palm fruit (Henderson and Osborne 1999; Tranbarger et al., 2011; Nurniwalis, 2017). An autocatalytic burst of ethylene produced in mesocarp tissues was detected during the ripening stages which indicated the characteristics of a climacteric fruit. Oil palm research on ethylene has been limited but the possibility that ethylene may also be responsible for triggering oil production and other changes associated with fruit ripening has been examined but not in great detail (Sambanthamurthi et al., 2000). Using molecular approaches such as expressed sequence tags (EST) and transcriptome data analyses, gene transcripts associated with ethylene synthesis and signalling pathway have been identified from the oil palm mesocarp (Nurniwalis et al., 2008; Tranbarger et al., 2011). These findings indicate an important role for ethylene in the development and ripening process of the oil palm fruits.

Hence, this study was conducted to further our understanding of the role of ethylene in oil palm fruit development at the molecular level, focusing on the ethylene signalling pathway and in particular the ethylene receptor genes. In this article, we report the isolation of a gene encoding an ethylene response sensor (ERS)-type ethylene receptor from oil palm. Gene characterisation via sequence analysis, Southern and expression analysis were conducted and its role and possible manipulation in oil palm fruit development are discussed.

\section{MATERIALS AND METHODS}

\section{Plant Materials}

All oil palm tissues from the commercial tenera planting material used in the study were obtained from MPOB-UKM Research Station, Bangi, Selangor, Malaysia. Inflorescences were tagged at various weeks after anthesis (WAA) and fresh fruit bunches were harvested for their mesocarp and kernel tissues. Spear leaves were acquired from unopened leaf fronds, roots from 2-year old seedlings and germinated seedlings were one- to two-week old.

\section{Total RNA Isolation and cDNA Synthesis}

Total ribonucleic acid (RNA) was extracted from various oil palm tissues as described by Nurniwalis et al. (2008; 2015). Reverse transcription of total RNA into single stranded cDNA was performed using Superscript II Kit (Gibco BRL Technology Inc., New York, USA) according to the manufacturer's protocol in a $20 \mu \mathrm{l}$ reaction volume using $5 \mu \mathrm{g}$ of total RNA.

\section{Degenerate PCR}

Degenerate polymerase chain reaction (PCR) amplification was performed using degenerate primer pair designed based on the conserved regions of ethylene receptor genes from dicot [papaya (Acc. No. AF311942), tomato (Acc. No.: T07794), peach (Acc. No.: AAM73756) and tobacco (Acc. No.: AAB97160)] and monocot [rice (Acc. No: AF013979) and maize (Acc. No.: BAB13718]) plants. PCR amplification was carried out in a $50 \mu \mathrm{l}$ reaction mixture containing $50 \mathrm{ng} 15$ WAA cDNA, 1X PCR buffer (Perkin Elmer, USA), 0.2 mM dATP, $0.2 \mathrm{mM}$ dCTP, $0.2 \mathrm{mM}$ dGTP, $0.2 \mathrm{mM}$ dTTP, $2.5 \mu \mathrm{M} \mathrm{MgCl2} \mathrm{(Perkin} \mathrm{Elmer,} \mathrm{USA),} 0.6$ $\mu \mathrm{M}$ each of the degenerate primers EF1 (5' 5' CHTACKATTTTGAAGACTAC 3') and ER1 (5' GATGAAAAACGGCTAATGC 3') and 0.05U/ $\mu$ l AmpliTaq DNA polymerase enzyme (Perkin Elmer,USA). The PCR conditions were as follows: one cycle of $94^{\circ} \mathrm{C}$ for $5 \mathrm{~min}, 40$ cycles of $94^{\circ} \mathrm{C}$ for $1 \mathrm{~min}, 50^{\circ} \mathrm{C}$ for $1 \mathrm{~min}$ and $72^{\circ} \mathrm{C}$ for $1 \mathrm{~min}$ and $30 \mathrm{~s}$ and a final extension of $72^{\circ} \mathrm{C}$ for $10 \mathrm{~min}$.

\section{Rapid Amplification of cDNA Ends (RACE)}

Both 5' and 3' RACE were performed using SMART ${ }^{\mathrm{TM}}$ RACE cDNA Amplification and Advantage 2 PCR Kit (Clontech, USA). The first strand cDNA for both 5 'and $3{ }^{`}$ RACE was synthesised from $1 \mu \mathrm{g}$ of 17 WAA mesocarp total RNA following the manufacturer's instruction. For 3' RACE, PCR amplification was carried out in a $50 \mu \mathrm{l}$ reaction mixture containing $1 X$ Advantage 2 PCR buffer, 0.2 mM dNTP mix, 1X Advantage 2 Polymerase Mix, $1 \mathrm{X}$ universal primer A mix, $0.2 \mu \mathrm{M}$ EF3 primer (5 CTGAACAACGATTGATGGTAGAAAC $3^{\prime}$ ) and $100 \mathrm{ng}$ of $3^{\prime}$-RACE-Ready cDNA with the following conditions: $94^{\circ} \mathrm{C}(5 \mathrm{~s}), 72^{\circ} \mathrm{C}(3 \mathrm{~min})$ for five cycles; $94^{\circ} \mathrm{C}(5 \mathrm{~s}), 70^{\circ} \mathrm{C}(10 \mathrm{~s}), 72^{\circ} \mathrm{C}$ (3 $\left.\mathrm{min}\right)$ for five cycles; $94^{\circ} \mathrm{C}(5 \mathrm{~s}), 68^{\circ} \mathrm{C}(10 \mathrm{~s})$ and $72^{\circ} \mathrm{C}(3 \mathrm{~min})$ for 25 cycles and a final extension at $72^{\circ} \mathrm{C}$ for $10 \mathrm{~min}$.

For 5' RACE, PCR amplification was performed in a $50 \mu \mathrm{l}$ reaction mixture containing 1X Advantage 2 PCR buffer, $0.2 \mathrm{mM}$ dNTP mix, 1X Advantage 2 Polymerase Mix, 1X universal primer A mix, $0.2 \mu \mathrm{M}$ EF4A primer (5' CCTTGCCAGTGGGCATGCGTGTGG 3') and 
$100 \mathrm{ng}$ of $5^{\prime}$-RACE-Ready cDNA with the same conditions and procedures as described for 3' RACE.

\section{Generation of the Full-length and 3`UTR Probe}

The full-length cDNA was generated via longdistance PCR (LD PCR) using SMART TM RACE cDNA Amplification Kit. PCR amplification was carried out in a $50 \mu$ l reaction mixture containing $1 X$ Advantage 2 PCR buffer, 1XAdvantage 2 Polymerase Mix, $0.2 \mathrm{mM}$ dNTP mix, $0.2 \mu \mathrm{M}$ gene-specific primers EF11(5' GGAATGTAAGGGCAAGGTAGTAATTG $\left.3^{`}\right)$ and EGER9 (5` GCT TAA ACG TTC AAA TAT ATT ATA GCA AGC 3'), 100 ng of 3' RACE-Ready cDNA with the following conditions: $94^{\circ} \mathrm{C}(5 \mathrm{~s})$, $72^{\circ} \mathrm{C}$ (3 min) for five cycles; $94^{\circ} \mathrm{C}(5 \mathrm{~s}), 70^{\circ} \mathrm{C}(10 \mathrm{~s})$, $72^{\circ} \mathrm{C}(3 \mathrm{~min})$ for five cycles; $94^{\circ} \mathrm{C}(5 \mathrm{~s}), 68^{\circ} \mathrm{C}(10 \mathrm{~s})$ and $72^{\circ} \mathrm{C}$ (3 $\left.\mathrm{min}\right)$ for 22 cycles and a final extension at $72^{\circ} \mathrm{C}$ for $7 \mathrm{~min}$.

The 3' UTR probe was generated via PCR in a $50 \mu$ reaction mixture containing $1 X$ BD Advantage buffer, $1 \mathrm{X}$ dNTP mix, $0.2 \mathrm{mM}$ each of gene-specific primers EF12 (5' CGG TTT GAA TGT CTG GTT AGC AAT ACC 3') and EGER9, 1X BD Advantage 2 Polymerase and $0.5 \mu \mathrm{g}$ of the plasmid DNA (EGER D3) with the following conditions: $95^{\circ} \mathrm{C}(1$ $\mathrm{min}), 95^{\circ} \mathrm{C}(30 \mathrm{~s}), 60^{\circ} \mathrm{C}$ (3 $\left.\mathrm{min}\right)$ for 30 cycles; a final extension at $60^{\circ} \mathrm{C}$ for $3 \mathrm{~s}$.

\section{Cloning and Sequencing Analyses}

PCR products purified using QIAquick Gel Extraction Kit (Qiagen, Germany), were individually cloned into pCR2.1 ${ }^{\circledR}$ vector and transformed into One Shot ${ }^{\circledR}$ Chemically Competent Escherichia coli TOP10 following the manufacturer's instruction (Invitrogen, USA). Plasmid DNA was isolated using QIAgen Plasmid Mini Kit (Qiagen, Germany) and the inserts were verified by EcoRI digestion. Sequence analysis was performed using DNASIS (Hitachi Software Package, 1997) and Biology Workbench Version 3.2 (http://workbench.sdsc. edu.). NCBI-BLAST (http://blast.ncbi.nlm.nih. gov/Blast.cgi) was used to search for similarities in the GenBank database. Prediction of transmembrane segments was performed using TMAP from Biology Workbench. Protein motifs were analysed using conserved domain search (Marchler-Bauer et al., 2017) and Prosite (http://prosite.expasy.org/ scanprosite /).

\section{Expression Analyses}

For dot blot analysis, blotting, preparation and fixation of RNA to a nylon charged membrane (Hybond-N+, Amersham, USA) was carried out as described by Sambrook and Russell (2001). The blotting manifold set up and preparation of the RNA $(10 \mu \mathrm{g})$ in RNA denaturation containing 66\% (v/v) deionised formamide, $21 \%(\mathrm{v} / \mathrm{v})$ formaldehyde and 1.3X MPOS buffer) solution was performed as described by Nurniwalis (2006).

For northern hybridisation, $15 \mu \mathrm{g}$ of total RNA was denatured at $55^{\circ} \mathrm{C}$ for $15 \mathrm{~min}$ in a GFP mixture containing $78 \%(\mathrm{v} / \mathrm{v})$ deionised formamide, $16 \%(\mathrm{v} / \mathrm{v})$ deionised glyoxal and 10 $\mathrm{mM}$ sodium phosphate buffer. The denatured total RNA was electrophoresed on $1.2 \%(\mathrm{w} / \mathrm{v})$ agarose gel and transferred to nylon charged membrane (Hybond-N ${ }^{+}$, Amersham, USA) overnight by capillary blotting as described by Nurniwalis (2006).

The blot was probed with the degenerate PCR fragment, full-length and 3' UTR fragments of the EGER D3 ethylene receptor gene. Hybridisation of the membrane with the $\alpha{ }^{32} \mathrm{P}$ labelled probe was performed in a buffer containing 5X SSC, 5X Denhardt, $0.5 \%$ (w/v) sodium dodecyl sulphate (SDS), $50 \%$ formamide at $42^{\circ} \mathrm{C}$ overnight. Washing of the membrane was performed using $2 X$ SSC, $0.1 \%(\mathrm{w} / \mathrm{v})$ SDS for $10 \mathrm{~min}$ at $60^{\circ} \mathrm{C}, 1 \mathrm{X}$ SSC, $0.1 \%$ SDS $(\mathrm{w} / \mathrm{v})$ for $15 \mathrm{~min}$ at $60^{\circ} \mathrm{C}$ and $0.5 \mathrm{X}$ SSC, $0.1 \%$ SDS $(\mathrm{w} / \mathrm{v})$ for $30 \mathrm{~min}$ at $60^{\circ} \mathrm{C}$. Membrane exposure to X-ray film was performed for three days at $-80^{\circ} \mathrm{C}$ with an intensifying screen.

\section{Southern Analysis}

Genomic DNA from oil palm leaf was extracted according to the modified Cetylatrimethyl ammonium bromide (CTAB) method of Doyle and Doyle (1990). A total of $30 \mu \mathrm{g}$ of DNA was digested individually with BamHI, EcoRI and XbaI. The digested DNA was electrophoresed on $1 \%$ $(\mathrm{w} / \mathrm{v})$ agarose and transferred onto nylon charged membrane via capillary blotting. Hybridisation was performed using the full-length and 3' UTR probes. Hybridisation, washing and generation of blotting signal was performed similarly as described for dot blot and northern analyses with a few modifications on the temperature and hybridisation buffer. The hybridisation buffer consists of 6XSSC, 5X Denhardt, $0.5 \%(\mathrm{w} / \mathrm{v})$ SDS and the hybridisation reaction was carried out at $55^{\circ} \mathrm{C}$. Washing of the blot was carried out in 4 X SSC for $5 \mathrm{~min}$ at $55^{\circ} \mathrm{C}$ and $2 \mathrm{X} \mathrm{SSC}, 0.1 \%$ SDS (w/v) for $30 \mathrm{~min}$ at $55^{\circ} \mathrm{C}$.

\section{RESULTS AND DISCUSSION}

\section{Degenerate PCR, 5' and 3' RACE Amplification}

Degenerate PCR resulted in the amplification of a single PCR product from 17 WAA mesocarp CDNA and the success in cloning of the PCR product is shown in Figure 1. The partial cDNA contains 726 nucleotides and the nucleotide sequence analysis provided the necessary information to design genespecific primers in the efforts to obtain the complete cDNA. 


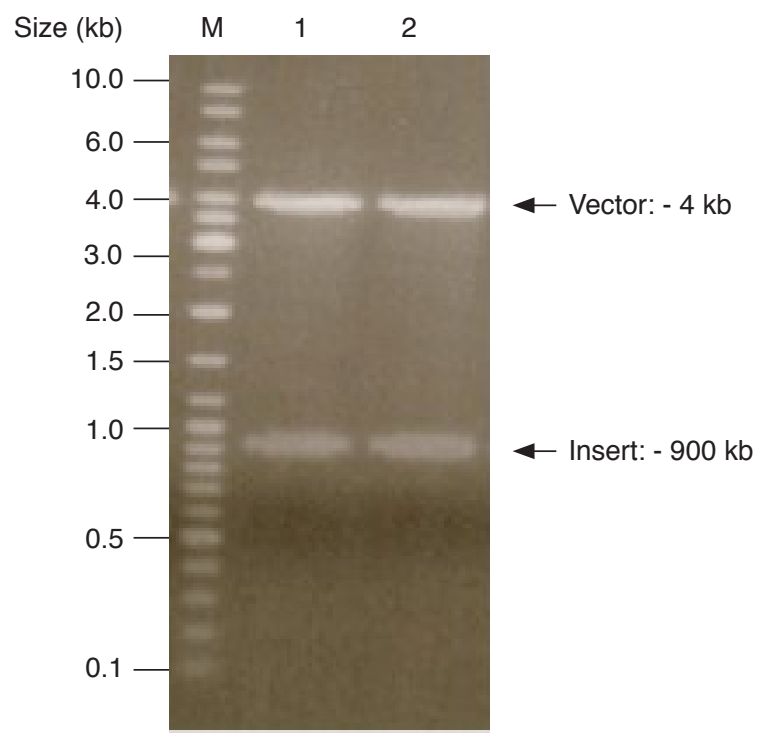

Figure 1. EcoRI digestion analysis of the plasmids carrying the degenerate polymerase chain reaction (PCR) products on $1 \%(w / v)$ agarose gel electrophoresis. Lanes 1 and 2 represent the digested plasmids carrying the insert. $M$ is Gene Ruler DNA Ladder Mix (Fermentas).

Amplification of the 5' and $3^{\prime}$ regions of the cDNA via $5^{\prime}$ and $3^{\prime}$ RACE resulted in the amplification of singular PCR products of about $900 \mathrm{bp}$ (Figure 2) and $1.1 \mathrm{~kb}$ (Figure 2) in size, respectively. DNA sequence analyses showed that the 5' RACE cDNA is $747 \mathrm{bp}$ whereas the $3^{\prime}$ RACE cDNA contains 1053 nucleotides including a $28 \mathrm{bp}$ poly $(\mathrm{A})^{+}$tail. Through the assembly of the degenerate PCR, 5 and 3' RACE cDNA sequences, an overlap of 225 and 74 nucleotides at the $5^{\prime}$ and $3^{\prime}$ regions of the degenerate PCR CDNA was observed. The $5^{\prime}$ RACE PCR product is $100 \%$ identical to the degenerate PCR cDNA sequence while the 3' RACE PCR product has 99\% identity, both of which are within the overlapping regions at the nucleotide level.

\section{Generation and Sequence Analysis of EGER D3}

Reconstitution of all three sequences (degenerate PCR, 5' and 3' RACE) resulted in the successful amplification of the full-length cDNA encoding for an ethylene receptor gene designated as EGER D3. EGER D3 is $2197 \mathrm{bp}$ in length [excluding the poly $(\mathrm{A})^{+}$tail] and contains a $1890 \mathrm{bp}$ open reading frame (ORF) (Figure 3). The ORF is flanked by $42 \mathrm{bp}$ of $5^{\prime}$ untranslated region (UTR), $265 \mathrm{bp}$ of 3' UTR and encodes a polypeptide of 629 amino acid residues. The predicted polypeptide has a deduced molecular mass of $70.013 \mathrm{kDa}$. The predicted value is similar to the ethylene receptors ERS1 (68 kDA) from Arabidopsis (Hall et al., 2000), Cm-ERS1 (75 kDA) from melon (Takahashi et al., 2002) and Nt-ERS1 (70 kDA) from tobacco (Terajima et al., 2001).

The sequence flanking the start codon site matched the canonical initiation motif, $\mathrm{A}[\mathrm{A} / \mathrm{C} / \mathrm{T} / \mathrm{G}]$ [A/C/T/G]ATGG as described by Kozak (1999). At the $3^{\prime}$ UTR region, two putative polyadenylation sites were present at nucleotide position 1968 to 1973 and 2177 to 2182 . It contained $4-5$ of a six

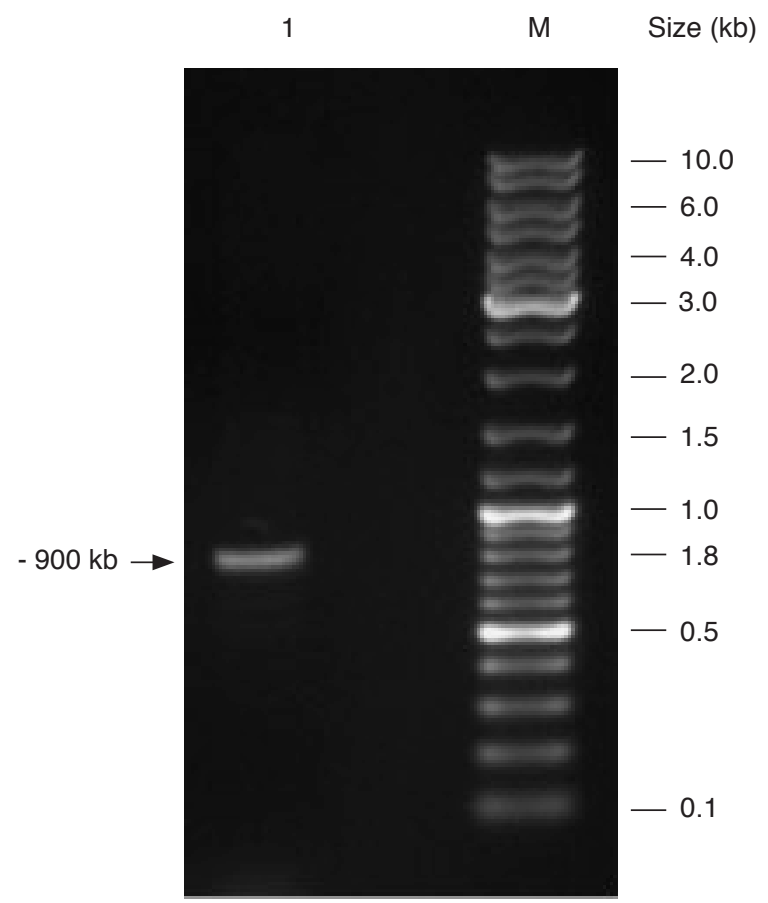

(A)

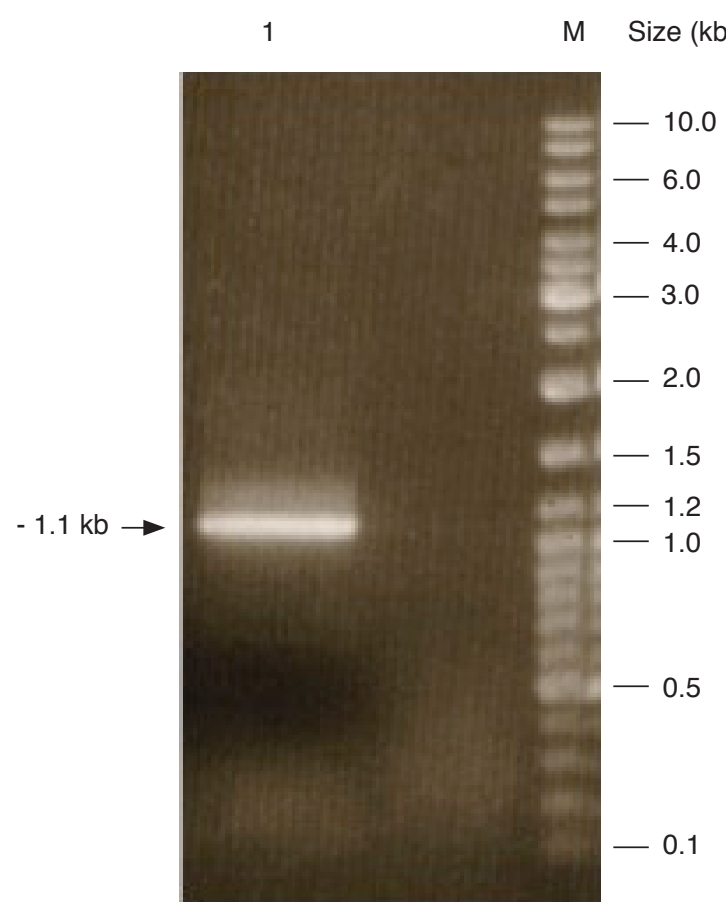

(B)

Figure 2. Analysis of the RACE PCR products by electrophoresis on $1 \%$ (w/v) agarose gel. A and B represents the $5^{\prime}$ and $3^{\prime}$ RACE PCR products. Lane $1=$ the amplified 5' RACE product, lane 2 = the amplified 3' RACE product and M= Gene Ruler DNA Ladder Mix (Fermentas). 
1 ggaatgtaagggcaaggtagtaattgcagtggttgctggaagatggagggttgtgactgc 60

$\begin{array}{llllllllllllllllllllllll}7 & \mathrm{~F} & \mathrm{E} & \mathrm{P} & \mathrm{Q} & \mathrm{W} & \mathrm{P} & \mathrm{A} & \mathrm{E} & \mathrm{E} & \mathrm{L} & \mathrm{L} & \mathrm{I} & \mathrm{K} & \mathrm{Y} & \mathrm{Q} & \mathrm{Y} & \mathrm{I} & \mathrm{S} & \mathrm{D} & \mathrm{F} & & 26\end{array}$

61 tttgagccacaatggcctgctgaagaacttctaattaaatatcaatacatatcagatttc 120

121 ttcatagccettgcttatttctctattccacttgagctcatttattttgtgaagaagtct 180

181 tccttcttccatatagatgggttctggttcagtttggtgcatttatcatcctttgtgga 240

241 gcaacccatctcataaacttgtggactttcacagttcactcaaaaactgttgccattgtt 300

$\begin{array}{lllllllllllllllllllllll}87 & \text { M } & \text { T } & \text { V } & \text { A } & \text { K } & \text { I } & \text { S } & \text { T } & \text { A } & \text { A } & \text { V } & \text { S } & \text { C } & \text { A } & \text { T } & \text { A } & \text { L } & \text { M } & \text { L } & \text { V } & 106\end{array}$

301 atgactgttgcaaaaatttcaactgccgctgtgtcctgtgcaacagctctaatgcttgtt 360

$\begin{array}{lllllllllllllllllllllll}107 & \mathrm{H} & \mathrm{I} & \mathrm{I} & \mathrm{P} & \mathrm{D} & \mathrm{L} & \mathrm{L} & \mathrm{S} & \mathrm{V} & \mathrm{K} & \mathrm{T} & \mathrm{R} & \mathrm{E} & \mathrm{L} & \mathrm{F} & \mathrm{L} & \mathrm{K} & \mathrm{S} & \mathrm{K} & \text { A } & & 126\end{array}$

361 catatcattcctgatttgctgagtgtaaagacaagagagttgtttttgaagagtaaagct 420

$\begin{array}{lllllllllllllllllllllll}127 & \mathrm{E} & \mathrm{E} & \mathrm{L} & \mathrm{D} & \mathrm{R} & \mathrm{E} & \mathrm{M} & \mathrm{G} & \mathrm{L} & \mathrm{I} & \mathrm{R} & \mathrm{T} & \mathrm{Q} & \mathrm{E} & \mathrm{E} & \mathrm{T} & \mathrm{G} & \mathrm{R} & \mathrm{H} & \mathrm{V} & & 146\end{array}$

421 gaagaactggatagagaaatgggcttgatacggacacaggaagaaacaggaagacatgtt 480

$\begin{array}{llllllllllllllllllllll}147 & \mathrm{R} & \mathrm{M} & \mathrm{L} & \mathrm{T} & \mathrm{H} & \mathrm{E} & \mathrm{I} & \mathrm{R} & \mathrm{S} & \mathrm{T} & L & D & R & H & T & I & L & K & T & T & 166\end{array}$

481 agaatgcttacgcatgaaatcagaagcacacttgatagacatactatattaaagactacc 540

$\begin{array}{llllllllllllllllllllll}167 & L & V & E & L & G & R & T & L & G & L & E & E & C & A & L & W & M & P & S & R & 186\end{array}$

541 cttgtggagttggggaggactttgggtttggaggaatgtgcactctggatgccatcacgt 600

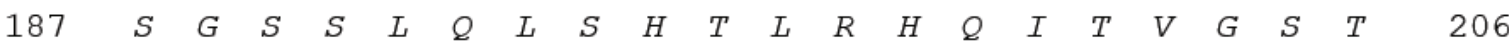

601 agtggttcaagtcttcagctttctcataccctgcggcaccagattacagttgggtcaact 660

$\begin{array}{llllllllllllllllllllll}207 & V & P & I & N & H & S & I & V & N & Q & V & F & S & S & S & H & A & I & I & I & 226\end{array}$

661 gtaccaattaatcattctatagtcaatcaagtgtttagtagcagtcatgcaataataatt 720

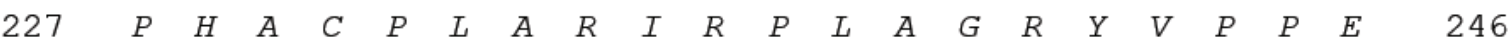

721 ccacacgcatgcccactggcaaggattcggcctcttgcaggaagatatgtcccaccagag 780

$\begin{array}{llllllllllllllllllllll}247 & V & A & A & V & R & V & P & L & L & H & L & S & N & F & Q & I & N & D & W & P & 266\end{array}$

781 gtggctgcagtgagagttcctcttttgcatctttcaaatttccaaattaatgattggcca 840

$\begin{array}{llllllllllllllllllllll}267 & E & L & S & A & K & S & Y & A & V & M & V & L & M & L & P & S & D & S & A & R & 286\end{array}$

841 gagctttctgcaaaagttatgctgtgatggttttgatgctcccatcagatagtgcaaga 900

$\begin{array}{llllllllllllllllllllll}287 & K & W & H & I & H & E & L & E & L & V & E & V & V & A & D & Q & V & A & V & A & 306\end{array}$

901 aaatggcacattcatgaactggagcttgttgaggtggttgctgatcaggtagcggtagca 960

$\begin{array}{lllllllllllllllllllllll}307 & L & S & H & \text { A } & \text { A } & \text { I } & \text { L } & \text { E } & \text { E } & \text { S } & \text { M } & \text { R } & \text { A } & \text { R } & \text { D } & \text { L } & \text { L } & \text { M } & \text { E } & \text { Q } & & 326\end{array}$

961 cttcacatgctgctattctggaagaatctatgcgggcacgtgatttactcatggaacaa 1020

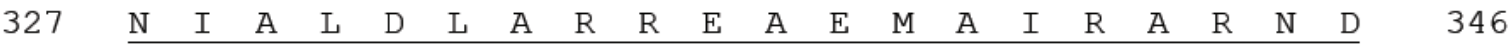

1021 aatattgccttagatttggctcggcgggaggcagaaatggccatacgtgctcgcaatgat 1080 \begin{tabular}{lllll|lllllllll|llllllllllll}
347 & $F$ & L & $A$ & V & M & N & H & E & M & R & T & P & M & H & A & I & I & A & L & S & & 366
\end{tabular}

1081 tttctagctgtcatgaaccatgaaatgcggactccaatgcatgcaattattgctcttct 1140 
1141 tccctgcttctcgaaactgagctcactcctgaacaacgattgatggtagaaaccatattg 1200

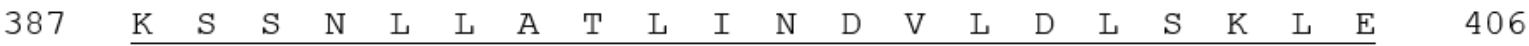

1201 aagagtagcaaccttctagctacgcttatcaatgatgttttagatctgtctaaactcgag 1260

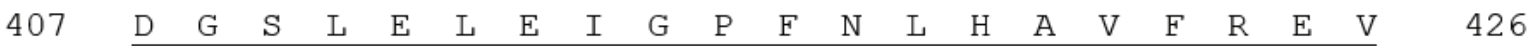

1261 gatggaagccttgagttagagattggaccttcaatcttcatgcagttttagagaggtc 1320

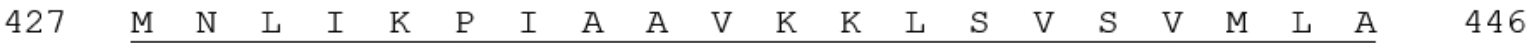

1321 atgaatttgataaagccaattgcagctgtgaagaaattgtcagtgtcagtgatgttggcg 1380

\begin{tabular}{llllllllllllll|llllllllll}
447 & $\mathrm{P}$ & $\mathrm{D}$ & $\mathrm{L}$ & $\mathrm{P}$ & $\mathrm{L}$ & $\mathrm{C}$ & $\mathrm{A}$ & $\mathrm{I}$ & $\mathrm{G}$ & $\mathrm{D}$ & $\mathrm{E}$ & $\mathrm{K}$ & $\mathrm{R}$ & $\mathrm{L}$ & $\mathrm{M}$ & $\mathrm{Q}$ & $\mathrm{T}$ & $\mathrm{I}$ & $\mathrm{L}$ & $\mathrm{N}$ & 466
\end{tabular}

1381 ccagacttgccattgtgtgccattggtgatgaaaagcggctcatgcagactatttaaat 1440

$\begin{array}{lllllllllllllllllllllll}467 & \mathrm{I} & \mathrm{A} & \mathrm{G} & \mathrm{N} & \mathrm{A} & \mathrm{V} & \mathrm{K} & \mathrm{F} & \mathrm{T} & \mathrm{K} & \mathrm{E} & \mathrm{G} & \mathrm{R} & \mathrm{I} & \mathrm{S} & \mathrm{L} & \mathrm{T} & \mathrm{A} & \mathrm{S} & \mathrm{V} & 486\end{array}$

1441 attgctggtaatgctgttaaatttacaaaggagggccgcatttcacttacagcttcagtt 1500

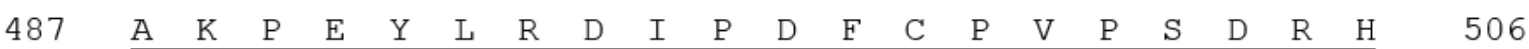

1501 gccaagccagaatatttgagggacattcctgacttctgtccggttcccagtgatcggcat 1560

\begin{tabular}{lllllll|llllllllllllllll}
507 & $\mathrm{~F}$ & $\mathrm{Y}$ & $\mathrm{L}$ & $\mathrm{K}$ & $\mathrm{V}$ & $\mathrm{Q}$ & $\mathrm{V}$ & $\mathrm{K}$ & $\mathrm{D}$ & $\mathrm{T}$ & $\mathrm{G}$ & $\mathrm{C}$ & $\mathrm{G}$ & $\mathrm{I}$ & $\mathrm{S}$ & $\mathrm{P}$ & $\mathrm{Q}$ & $\mathrm{D}$ & $\mathrm{K}$ & $\mathrm{A}$ & 526
\end{tabular}

1561 ttttacctgaaagttcaggttaaggatactggttgcggaatcagtccccaagacaaagca 1620

\begin{tabular}{ll|lllll|llllllllllllllllll}
527 & $\mathrm{H}$ & $\mathrm{L}$ & $\mathrm{F}$ & $\mathrm{T}$ & $\mathrm{K}$ & $\mathrm{F}$ & $\mathrm{A}$ & $\mathrm{Q}$ & $\mathrm{A}$ & $\mathrm{Q}$ & $\mathrm{S}$ & $\mathrm{G}$ & $\mathrm{K}$ & $\mathrm{N}$ & $\mathrm{Q}$ & $\mathrm{G}$ & $\mathrm{Y}$ & $\mathrm{S}$ & $\mathrm{G}$ & $\mathrm{S}$ & 546
\end{tabular}

1621 catttatttaccaaatttgcacaggctcaaagtggaaaaaaccaaggatatagcggcagt 1680

\begin{tabular}{lllll|lllllllllllllllll}
547 & G & L & G & L & A & I & C & K & R & F & V & S & L & M & E & G & H & I & W & L & 566
\end{tabular}

1681 ggacttgggcttgccatttgcaagagatttgtgagtcttatggaaggacacatctggctt 1740

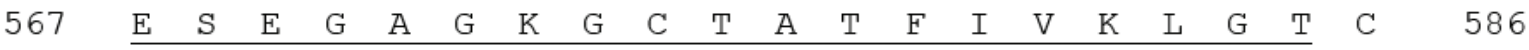

1741 gaaagtgaaggtgctggtaagggttgtacagccacgttcatcgtgaagcttgggacgtgt 1800

$\begin{array}{lllllllllllllllllllllllllllllll}587 & \mathrm{E} & \mathrm{N} & \mathrm{P} & \mathrm{I} & \mathrm{G} & \mathrm{F} & \mathrm{Q} & \mathrm{Q} & \mathrm{Q} & \mathrm{V} & \mathrm{V} & \mathrm{P} & \mathrm{K} & \mathrm{A} & \mathrm{R} & \mathrm{P} & \mathrm{S} & \mathrm{H} & \mathrm{K} & \mathrm{E} & & 606\end{array}$

1801 gaaaatccaattggttttcagcaacaagttgtgcctaaagcaaggccaagtcataaagag 1860

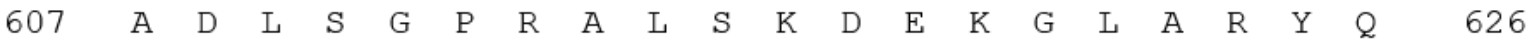

1861 gcagatctttcgggcccaagagcattgtcaaaagacgagaaaggactggctcgataccaa 1920

$627 \mathrm{~K} \quad \mathrm{~S} \quad \mathrm{~V}$ * $\mathrm{EF} 12 \longrightarrow 630$

1921 aaaagtgtatagacggtttgaatgtctggttagcaataccaattttgataaaattcaatg 1980

1981 tgtgatatgtggaaatccatgattctgatgcttcagctagcacattttgttgcacaaat 2040

2041 gagaattgagcagctcttgcaatagtaaaggtagtactgtagaaatgctggttccaacac 2100

2101 tgacttgatggtagtatctattatttgaagcactgtatatcaacatccttctatcggctt 2160

2161 gattgaagcttgctataatatatttgaacgtttaagcaaaaaaaaaaaaaaaaaaaaa 2220

2221 aaaaa

Figure 3. Nucleotide and deduced amino acid sequences of the full-length EGER D3 cDNA. The nucleotide sequence is shown in lower case whereas the amino acid sequence is capitalised. Numerals at both ends of the nucleotide rows indicate nucleotide numbers. The start codon, (atg) and the stop codon, (tag) are in bold and marked with an asterisk, respectively. The putative polyadenylation signal is italicised and double underlined. Arrows represent specific (EF11, EF12) and complementary (EGER9) primer sequences designed for LD PCR and generation of 3' UTR gene-specific probe. The triple transmembrane domains I, II and III are shaded in blue boxes, the GAF domain from amino acid 158 to 309 are italicised whereas the histidine kinase (HK) domain from amino acid 326 to 585 is underlined. The five histidine kinase conserved motifs $(H, N, D, F, G)$ are boxed and the amino acid residues important for ethylene receptor function are in red and bold. 
nucleotide match of the conserved sequence found in most plants (Hunt, 2011). These polyadenylation sites provide alternative poly (A) site choice that has the potential to affect plant gene expression (Hunt, 2011).

Result from blastx homology search showed that the nucleotide sequence of EGER D3 exhibited a high sequence identity to predicted ethylene receptors from a wide range of plant species. The top three highest identity of $99 \%, 98 \%$ and $94 \%$ was found matching to a predicted probable ethylene response sensor 1 isoform X1 (XP_010921594.1) and isoform X2 (XP_010921597.1) from oil palm and a probable ethylene response sensor 1 from date palm (XP_008775899.1).

Comparison at the amino acid level with several established members of the ethylene receptor family from other plants such as rice (Yau et al., 2004), tomato (Klee and Tieman, 2002) and Arabidopsis (Chang et al., 1993; Hua et al., 1998) showed that the deduced EGER D3 protein is closely related to ERStype ethylene receptors (Table 1). Multiple sequence alignment of amino acids between EGER D3 and other ERS-type ethylene receptors from other plants showed that the EGER D3 deduced protein has two structural domains: a sensor (transmembrane) and a histidine kinase (transmitter) domain; and just like any other ERS-type ethylene receptors, it lacks the receiver domain (Figure 4 ).

The transmembrane domain located at the amino (N)-terminal was predicted to contain three potential transmembrane segments specifically located at amino acid positions 20 to 42, 50 to 70 and 82 to 110 (Figure 3). In Arabidopsis, the transmembrane domain is located within the endoplasmic reticulum membrane and is essential

TABLE 1. COMPARISON OF AMINO ACID SEQUENCE SIMILARITY (\%) BETWEEN EGER D3 AND THE ESTABLISHED MEMBERS OF THE ETHYLENE RECEPTOR FAMILIES OF ARABIDOPSIS (At), TOMATO (Le) AND RICE (Os) (BL2SEQ, Biology Workbench, Version 3.2, University of California, San Diego)

\begin{tabular}{cc}
\hline Ethylene receptors & EGER D3 (\%) \\
\hline At-ETR1 & 75 \\
At-ETR2 & 39 \\
At-ERS1 & 75 \\
At-ERS2 & 35 \\
At-EIN4 & 37 \\
Le-ETR1 & 74 \\
Le-ETR2 & 72 \\
Le-Nr & 71 \\
Le-ETR4 & 42 \\
Le-ETR5 & 41 \\
Le-ETR6 & 38 \\
Os-ETR2 & 41 \\
Os-ETR3 & 40 \\
Os-ETR4 & 34 \\
Os-ERS1 & 84 \\
Os-ERS2 & 72 \\
\hline
\end{tabular}

for ethylene-binding (Schaller and Bleeker, 1995). Several conserved residues that are important to bind ethylene are also present in EGER D3. These include alanine at positions 31 and 102, isoleucine at position 62 and cysteine at position 65 (Figure 3). Site-directed mutagenesis of any of these amino acid residues has been shown to cause dominant insensitivity to ethylene (Chang et al., 1993; Schaller and Bleeker, 1995).

Two cysteine residues $\left(\mathrm{Cys}_{4}\right.$ and $\left.\mathrm{Cys}_{6}\right)$ important for the formation of disulfide-linked dimer at the transmembrane domain were also found at the N-terminal of the deduced EGER D3 protein. In addition, both $\mathrm{Cys}_{65}$ and $\mathrm{His}_{69}$ as found in EGER D3 have also been shown to serve as ligands for the copper ion to bind to ethylene. Ethylene receptors have been shown to form disulfide-linked dimers, whereby each dimer bind a single ethylene with the assistance of a copper ion cofactor (Schaller and Bleeker, 1995; Rodríguez et al., 1999) through the action of the copper transporter RAN1 to balance the ethylene receptors and copper homeostasis (Binder et al., 2010).

Following the transmembrane domain, a subdomain called GAF was detected. The GAF domain was located at amino acid positions 158 to 308 (Figure 3). Earlier studies have suggested that the GAF domain is known to bind small molecules such as cyclic guanosine monophosphate (cGMP) (Aravind and Ponting, 1997). A decade later, Gao et al. (2008) demonstrated protein-protein interactions between the GAF domains using yeast two-hybrid analysis of the Arabidopsis ethylene receptor family, suggesting that it plays an important role in mediating signalling between the ethylene receptors.

Next to the GAF domain towards the carboxyl termini is a histidine kinase (HK) domain located at amino acid positions 350 to 585 (Figure 3). The HK domain comprises of His kinase A (His KA) and a histidine kinase-like ATPase (HATPase-c) and is similar to the bacterial two-component HK signal system, which is commonly found in prokaryotes but not in eukaryotes (Chang, 2016). The deduced EGER D3 protein contained all five HK conserved motifs found in bacteria (H, N, D, F and G) which are essential for HK activity (Mascher et al., 2006). The motifs are arranged in the same order and spacing as in ERS-type ethylene receptor polypeptides of other plants (Figure 4). Comparison with the ERS-type ethylene receptors revealed that all five HK motifs are well conserved with one another (Figure 4). The $\mathrm{F}$ and $\mathrm{G}$ motifs in EGER D3 is 100\% identical to that of the bacterial two-component system whereas motifs $\mathrm{H}, \mathrm{N}$ and $\mathrm{D}$ have sequence similarities of $78 \%, 83 \%$ and $78 \%$ identity, respectively. In bacteria, a stimulus is sensed by a $\mathrm{HK}$ and is then transmitted to a response regulator (RR), which results in signalling (Mascher et al., 2006). The HK catalyses 


\begin{tabular}{|c|c|}
\hline & 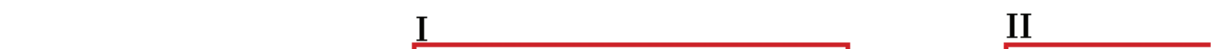 \\
\hline PS-ERS1 & MMESCECIDTPYPPDELLVKYYYISDVLIALAYFSIPVELIYFVQKSAFFPYRWVLMQFG \\
\hline & -MESCDCIDTPC PGEELLVKYYY ISDVLIALAYFSIPLELIY FVHKSAC EPYRWVLMQFG \\
\hline & MMESCDCIDAQWP PDE LLVKYYYISDFLIALAYFSIPLELIY FVQKSAF EPYRVLMQFG \\
\hline & -MESCDCFETHVNQDDLLVKYYYISDALIALAYFSIPLELIYFVKKSSF FPYRVLIQFG \\
\hline & -MESCDCIEALLPTGDLLVKYOY ISDFEIALAYFSIPLELIYFVHKSAC FYRWVLMQFG \\
\hline & -MDSCACIETQWPADELLVKYOYISDFFIALAYFSIPLELIYFVQKSAFEPYRW \\
\hline & -MDGCDCIEPLWPTDELLIKYYYISDFFIALAYFSIPLELIY FVKKSSF FPYRW \\
\hline & -MEGCDCFEPQWPAEELLIKYQYISDFFIALAYFSIPLELIYFVKKSSF HPYRW \\
\hline \multirow[t]{2}{*}{ Ma-ERS1 } & 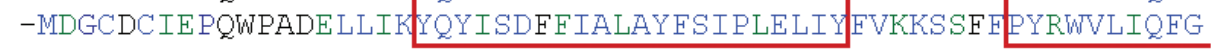 \\
\hline & 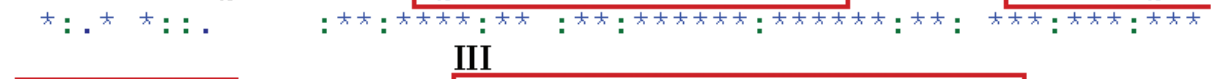 \\
\hline$S-E R S 1$ & AFIVLCGATHA $I N L W T F S A H S K$ AVAVVMTIAKVSCAIVSCATALMLVHIIADLLSVKTRE \\
\hline & AFIVLCGATHH INLWTFSMHSKAVAVVMTIAKVACAAVSCVTAL] \\
\hline & AFIVLCGATHELNLWTESMHSKAVAVVMTVAKVACAIVSCATAL] \\
\hline & AFIILCGATHA INLWMF FMHSKAVA. \\
\hline & AFIVLCGATHHISLWTEFMHSK TVAV \\
\hline RS1 & AFIVLCGATHL INLWTFSMHSK IVAMVMTIA \\
\hline RS1 & AFIVLCGATHL FNLWTFTTHTKIVAMVMTV \\
\hline MSP2 & AFIILCGATHI INLWTFTVHSK TVAIVMTVAKISTAAVSCATAL] \\
\hline \multirow[t]{2}{*}{ Ma-ERS1 } & AFIVLCGATHI NLWTFALHSR ILAIVMTVAKVSTAVVSCATALI \\
\hline & 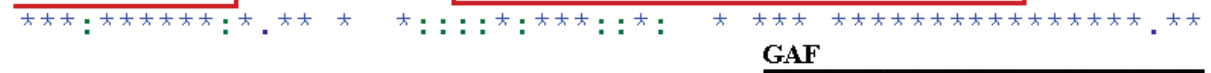 \\
\hline & LELKNKAEELDREMGLILTQEETGRHVRMLTHEIRSTI DRHTII \\
\hline & DREMGLILTQEETGRHVRMLTHEIRSTIPRHTII \\
\hline & ILKNKAEQLDREMGLILTQEETGRHVRMLTHEIRSTI DRDTILKTTLVE LGKTLGLEEC \\
\hline -ERS1 & FLKKKADE LDREMGLILTQEETGRHVRMLTHGIRRTI DRHTILRTTLVELGKTLCLEEC \\
\hline$e-N R$ & FLKTRAEE LDKEMGLIIRQEETGRHVRMLTHEIRSTL DRHTI LKTTLVE LGRTLDLAEC \\
\hline RS1 & JELKNKAEELDREMGLIRTQEETGRHVRMLTHEIRSTLDRHTILK \\
\hline R.S1 & LFLKNKAEQLDREMGLIRTQEETGRHVRMLTHEIRSTIDRHTI LKTTLVE LGGTL \\
\hline & JELKKAEELDREMGLIRTQEETGRHVRMLTHEIRSTIDRHTILKTTLVELGRTLGLEEC \\
\hline & LFLKNKAEELDREMGLIRTQEETEGNVH \\
\hline & 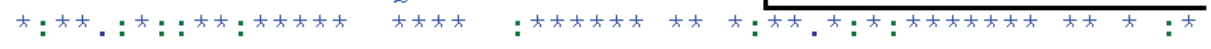 \\
\hline
\end{tabular}

PS-ERS1 $\mathrm{Cp}-\mathrm{ER}$

Cm-ERS1

At-ERS1

Le-NR

DI-ERS1

OS-ERS1

MSP2

Ma-ERS1

PS-ERS1

$\mathrm{Cp}-\mathrm{ER}$

Cm-ERS1

At-ERS1

Le-NR

DI-ERS1

OS-ERS1

MSP2

Ma-ERS1

PS-ERS1

$\mathrm{CP}-\mathrm{ER}$

Cm-ERS1

At-ERS1

Le-NR

DI-ERSI

OS-ERS1

MSP2

Ma-ERS1
ALWMPSRSGLNLQLSHTLTYHVQVGSTVPTNLPIVNEVFNSPRATRIPHTCPLARIRPLV ALWMPSRSGLNMQLSHTLNYHIQVGSTLPTNLPIVNEVFNNARAMRIPYTCPLARIRPLV ALWMPSRNGLSLQLSHALNYQIPVGTNIPINLPVVNDVFNSNRAICVPYTCQLARVRTPV ALWMPSQSGLYLQLSHTLSHKIQVGSSVPINLPIINE LFNSAQAMHI PHSCPLAKIGPPV ALWMPCQGGLTLQLSHNLNNLIPLGSTVPINLPI INEIFSSPEAIQI PHTNPLARMRNTV ALTMPSRTGMNLQLSHTLRHQI PVGSTVSTNLPIVTQVENSNQAIKI PHTCPLARIGPTA ALWMPSRSGSSLQLSHTLRHQITVGSTVSINLPVVNQVESSNRAIIIPHTSPLARIRPLA ALWMPSRSGSSLQLSHTLRHQITVGSTVPINHSIVNQVESSSHAIII PHACPLARIRPLA MLWMPSHSGTSLQLSHTLHHQIPTGSAVPINLPVVNQIESSNHAMIIPHTCRLARIWPLS

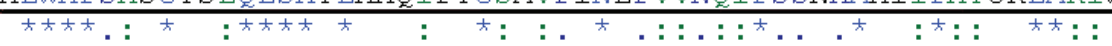

G-RYVPPEVVAVRVPLLHLSNFQINDWPDLSAKSFAIMVLILPTDSARKWRDHELELVDV G-RYVPPEVVAVRVPLLHLSNFQINDWPDHSAKSYAIMVLILPTDSARKTRDHELE LVEV GGRYLPPEVVAVRVPLLNLSNFQMNNWPDGSSRSYAIMVLILPTDSARKWRDHELELVDV G-RYSPPEVVSVRVPLLHLSNFQGSDWSDLSGKGYAIMVLILPTDGARKTRDHE LELVEN G-RYIPPEVVAVRVPLLHLSNET-NDWAELSTRSYAVMVLVLPMNGLRKTREHE LE LVQV G-RYVPPEVVAVRVPLLHLSNFQINDWPELSAKSYAVMVLMLPTDSARKWHDHE LDLIEV G-RYVPPEVAAVRVPLLHLSNFQINDWPELSAKSYAIMVLMLPSDSARKTWHVHE LELVEV G-RYVPPEVAAVRVPLLHLSNFQINDWPE LSAKSYAVMVLMLPSDSARKWWIHE LE LVEV V-RHVP PEVAAVRVPLLHLSNFQISDWSELSTKSYAVMVLILPSDSGRKWHVHELELVEV

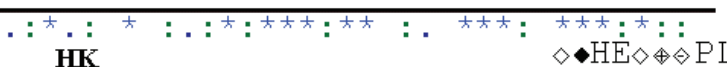

VADQVAVALAHAAILEESMRARDQLMF QNVALDLARREAEMAIHARNDF LAVMNHEMRTP VADQVAVAL SHAA I EESMRARDQLME QNVALNLARQEAEMAIHARNDF LAVMNHEMRTP VADQVAVAL SHAAILEESMRARDQLVD QNVALDLARREAETAIHARNDF LAVMNHEMRTP VADQVAVAL SHAAI LEESMHARDQLMF ONFALDKARQEAEMAVHARNDF LAVMNHEMRTP VADQVAVAL HAAI LEDSMRAHDQLME QNIALDVARQEAEMAIRARNDF LAVMNHEMRTP VADQVAVAL SHAAILEESMRARDMLME QNIALDMARREAEMAIRARNDF LAVMNHEMRTP VADQVAVAL SHAA I LEESMRARDLLMEQNVALDLARREAEMAIRARNDF LAVMNHEMRTP VADQVAVALAHAAILESMRARDLLME ONIALDLARREAEMAIRARNDF LAVMNHEMRTP VADQVAVALGHAAI LAESMRARDLLTEQNVALY LARQEAE LAIRARNDE LAVMNHEMOTP 
PS-ERS1

$\mathrm{Cp}-\mathrm{ER}$

Cm-ERS1

At-ERS1

Le-NR

DI-ERS 1

OS-ERS1

MSP2

Ma-ERS1

\section{PS-ERS1 \\ Cp-ER \\ CM-ERS1 \\ At-ERS1 \\ Le-NR \\ DI-ERSI \\ OS-ERS1 \\ MSP2}

Ma-ERS1

PS-ERS1

Cp-ER

CM-ERS1

At-ERS1

Le-NR

DI-ERSI

OS-ERSI

MSP2

Ma-ERS1

PS-ERS1

$\mathrm{CP}-\mathrm{ER}$

Cm-ERS 1

At-ERS1

Le-NR

DI-ERS 1

OS-ERS1

MSP2

Ma-ERS1

PS-ERS1

$C p-E R$

$\mathrm{Cm}-\mathrm{ER} \overline{\mathrm{S}} 1$

At-ERS1

Le-NR

DI-ERS 1

OS-ERS1

MSP2

Ma-ERS1
MHAIIALSS LLLETELTPEQRVMIETVLKS SNVLAALINDVLDLSRLEDGS LE LEMGKIN MHAIIALSSLLLETELTPEQRVMIETVLKSSNLLATLINDVLDLSRLEDGSLKLDSETEN MHAIIALSS LLLETELTPEQRVMIETILKS SNLLATLINDVLDLSRLEDGSLVLDMGSFN MHAI ISLSSLLLETELSPEQRVMIETILKSSNLVATLISDVLDLSRLEDGSLLLENEPFS MHAVIALCS LLLETDLTPEQRVMIETILKSSNLLATLINDVLDLSRLEDGILELENGTFN MKAVIALSSLLLEIELTPEQRVMIETVLKNSNLLAALINDVLELSRLEDGSLELDIRTFN MNAIIALSSLLLETE LTPEQRLMVETVLKSSNLLATLINDVLDLSKLEDGSLELEIKAFN MHAIIALSSLLLETELTPEQRLMVETILKSSNLLATLINDVLDLSKLEDGSLELEIGPFN LHATITLSSLLLETELSPEQRSMVETVLKSSSLLATLINDILDLSRLEDGRLELEIGDFN

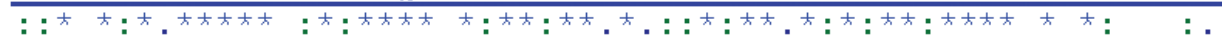
$\diamond \bullet Q \diamond \diamond \diamond \mathrm{N} \diamond \diamond \bullet \mathrm{NA}$

LHGVLEEVIE LIKPIASVKKLPITLILAPDLPDNAIGDVKR LMQTLLNVVGNAVKYTKEG LQGIFREVINLIKPITSVKKLSMTLIMAPDLPACAVGDEKR LMQAI LNVVGNAVKFTKEG LHAIFKEALDLIKPIASVKKLSMALILASDLPICAVGDEKR LMO I I LNIVGNGVKFTKEG LQAIFEEVISLIKPIASVKKLSTNLILSADLPTYAIGDEKR LMQTI LNIMGNAVKFTKEG LHGILREAVNLIKPIAS LKKLSITLALALDLPI LAVGDAKR LIQTLLNVAGNAVKFTKEG LHGIFREVLNMIKPITAVKKLS LTLMLS PDLPVVAVGDEKR LMQIMLNVVGNA VKFTKEG LHAVEKEVMSFIKPIAAIKRLSVSVMLAPDLPLCAIGDEKR LMQTI LNISGNAVKFTKEG LHAVFREVMNLIKPIAAVKKLSVSVMLAPDLPLCAIGDEKR LMQTI LNIAGNAVVKTKEG LHSVEREVMNE IKP IRAVKKLQVS LMLS PDLPLYAIGDEKR LMQIMLNVAANAVRETKEG

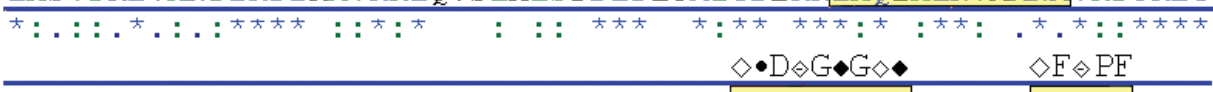
YVSIRASVAKPESLQDWRPPEFYPASSDGHFYIRVQVVDSGCGILPQDIPHLFTKFTQSQ YVTIVASVAKPDASRDW--PECY PVSSEGHFHLCVQVKDSGCGIHPQDIPHLFTKFAQPR HVSIIASIAKLDS LRDWRPTE FY PMQSDGQFY LRVQVVDSGCGIP PQDI PHLFTRF TQLQ YISIIASIMKPESLQELPSPEFEPVLSDSHFYLCVQVKDTGCGIHTQDIPLIFTKEVQPR HISIEASVAKPEYARDCHPPEMF PMPSDGQFYLRVQVRDTGCGISPQDIPLVFTKFAESR YVSVIASVAKAESLREWQAPEI FMVSSDSHFHLCVOVKDSGCGIS PQEIPHLFTKF TQLR HITLVASVVKADSLREFRTPDFHPTASDDNFYLKVQIKDTGCGISPQDLPQVFTKFPQSQ RISLTASVAKPEYLRDI--PDFCPVPSDRHFYLKVQVKDTGCGISPQDKAHLFTKFAQAQ DISLTASVARTDYLREFRALDFY PVASDGHFYLRVTIKDTGCGISHQDLPNLETKESQSQ

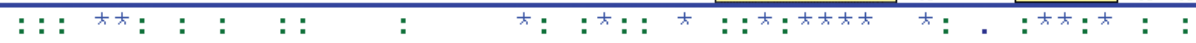
G•GLGL

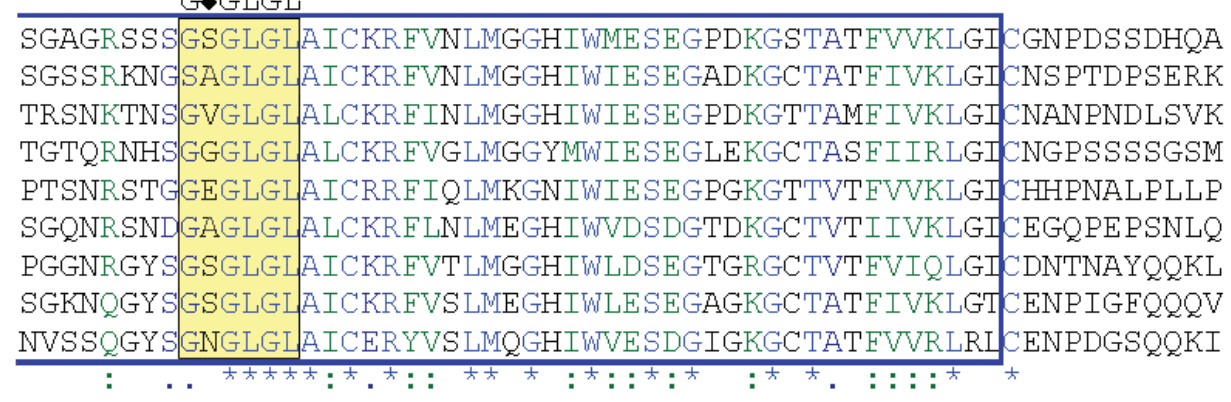

TTRGQAYSGSGGLARFKHLVNDGDIGFSNRRNQRSF

VGTKGQTTHGSGDLTRHKPLYRDNNGSTSSNPRYQRSF

QVAPIVNHRSADLHGQRPIFRETGQVAFSNSRYQRSL

ALHLAAKSQTRPWNW--------

MPPRGRLNKGSDDLFRYRQFR-GDDGGMSVNAQRYQRSL

VVSRRRLS--------------

IPLVWPSSGDADFVGPVPNAPNEEKGQASLKSRYQRSI

VPKARPSHKEADLSGPRALS-KDEKGLARYQKSV

LPLPWKKQT-QKFSSSRGMPTDPGGLED---

Figure 4. Amino acid sequence alignment of EGER D3 with ethylene receptors ERS1 from other plants. " ${ }^{* \prime}=$ single, fully conserved residue, $' \because '=$ conservation of strong groups, $\because '=$ conservation of weak groups whereas those without any symbol = no consensus (CLUSTWALW, Biology Workbench Version 3.2, University of California). The triple transmembrane domain region at the amino terminal are labelled I, II, III and are boxed in red. The GAF domain is boxed in black. The histidine kinase domain is boxed in blue. The five conserved motifs $(H, N, D, F$ and $G)$ in the histidine kinase domain found in bacteria protein kinase are shaded and symbols are labelled on top of the sequences according to Masher et al. (2006).

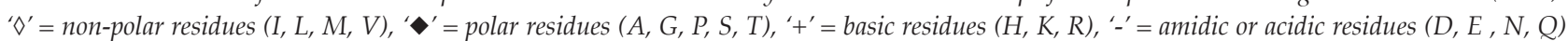
whereas ' $:$ ' = wild card position with less than $50 \%$ conservation in bacterial histidine kinases. The ERS1 amino acid sequences were obtained from GenBank: Arabidopsis thaliana At-ERS1 (Acc. No. U21952), Oryza sativa Os-ERS1 (Acc. No. AF013979), Pisum sativum Ps-ERS1 (Acc. No. AJ005829), Carica papaya Cp-ER (Acc. No. AF311942), Cucumis melo Cm-ERS1 (Acc. No. BAB13735), Lycopersicon esculentum Le-NR (Acc. No.U38666), Delphinium spp. L DI-ERS1 (Acc. No. AB106891) and Musa acuminata Ma-ERS1 (Acc. No. AF113748). 
the autophosphorylation of a conserved His residue and transfer the phosphate group to a conserved aspartate residue in the RR domain (Mascher et al., 2006). EGER D3 has a histidine (His354) residue in the histidine motif that may function as a phosphorylation site just like in the bacterial twocomponent signalling system, however, it does not contain the RR.

Histidine and/or serine/threonine kinase activity in vitro has been demonstrated in ethylene receptors from Arabidopsis (Gamble et al., 1998) and tobacco (Xie et al., 2003; Zhang et al., 2004). The different kinase activities however, do not show their dependence on the conserved His residue to transmit the signal (Xie et al., 2003; Zhang et al., 2004). There are also other strong evidence that show interactions between ethylene receptors, constitutive triple response 1 (CTR1) and ethyleneinsensitive 2 (EIN2) are the primary components mediating ethylene signalling as compared to the HK (Chang, 2016). In the absence of ethylene, the ethylene receptors activate the kinases in CTR1, which results in phosphorylation and inhibition of EIN2 function. On the other hand, when ethylene is detected, the receptor-CTR1 signalling is deactivated causing EIN2 to become dephosphorylated and releases the EIN2 C-ends via proteolytic cleavage, hence allowing the downstream ethylene signalling pathway to proceed and evoke ethylene responses in plants (Chang, 2016).

\section{Determination of Gene Copy Number}

Ethylene signalling is mediated by a family of receptors (Klee and Tieman, 2002; Yau et al., 2004; Chang, 2016). Therefore, to determine the organisation of the ethylene receptor family in the oil palm genome, Southern analysis was performed. Southern hybridisation using 3' UTR as the gene specific probe showed that at lowstringency conditions, the probe hybridised to a single fragment in the digested oil palm genomic DNA, indicating that there is probably one copy of the EGER D3 gene present in the oil palm genome (Figure 5). Using a gene specific probe containing the full-length sequence of EGER D3, Southern hybridisation at low stringency washing conditions detected the presence of multiple bands in both BamHI and EcoRI digested genomic DNA (Figure 5). The presence of multiple bands suggests that in oil palm, EGER D3 is a member of a multigene family. This is in agreement with ethylene receptors found in many dicot as well as monocot plants species such as Arabidopsis (Chang et al., 1993; Hua et al., 1998), tomato (Klee and Tieman, 2002), rice (Yau et al., 2004), peach (Rasori et al., 2002), melon (SatoNara et al., 1999), and tobacco (Xie et al., 2003). To date, there is at least one member of the ethylene receptor family identified in orchids (Thongkum et al., 2009) and a maximum of nine members in apple (Ireland et al., 2012).

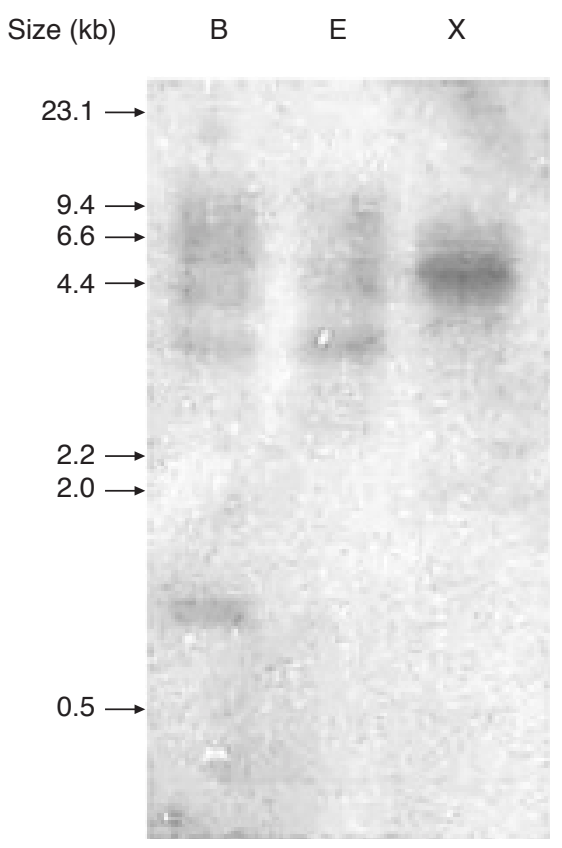

(B)

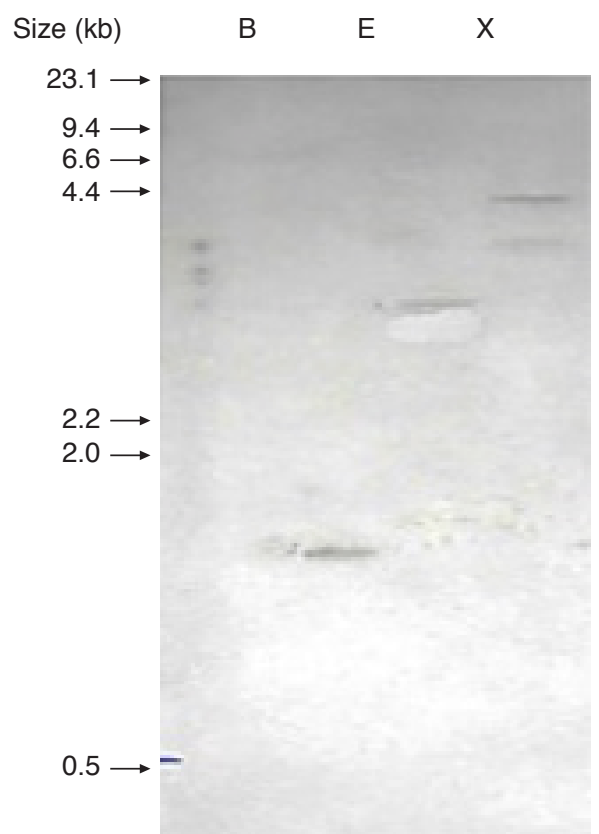

(B)

Figure 5. Southern blot hybridised with the 3' UTR (A) and full-length (B) EGER D3 probes. Each lane represents $30 \mu g$ of oil palm genomic DNA digested with different restriction enzymes. Lanes B, E, X represents DNA digested with Bam $H I, E c o R$ I and Xba I, respectively. 


\section{Expression Analysis}

Preliminary analysis on the expression pattern of the ethylene receptor gene was performed using dot blot analysis. The entire fragment amplified from the degenerate PCR amplification was used to probe the nylon charged membranes containing total RNA from the mesocarp at five different development stages, two developmental stages of kernel and spear leaf tissues. It was found that the labelled probe hybridised to all five mesocarp tissues with strong signal intensities. On the other hand, very faint signals were detected in kernel tissues at 12 and 13 WAA, as well as in leaves (Figure 6).

Northern blot hybridisation was then performed to confirm the expression pattern and determine the transcript size of the ethylene receptor gene in mesocarp tissues. An additional mesocarp tissue at 10 WAA was also included to represent oil palm fruit developmental stages from young until ripening. The full-length insert of EGER D3 and the 3' UTR probes hybridised to a single transcript of about 2.3 $\mathrm{kb}$, similar to the size of EGER D3 (Figure 6). The expression of EGER D3 appeared to be strong and it was differentially expressed in the mesocarp during oil palm fruit development. The expression in mesocarp tissue gradually increased from the early fruit developmental stages from 10 WAA up to 17 WAA and decreased slightly when the fruit has fully ripened. This result is in agreement with that found from the dot blot analysis. A similar expression pattern with the period when oil synthesis starts in the mesocarp was also observed based on the high expression of EGER D3 at 15 WAA. Similarly to EGER D3, increase in transcript levels of ERS-type ethylene receptors have also been observed during the ripening process in fruits such as melon (SatoNara et al., 1999) and peach (Rasori et al., 2002).

Fruit ripening is normally associated with changes in fruit texture, colour and softening of the flesh with an increase in the sweetness, flavour and aroma (McAtee et al., 2013). Unlike other fleshy fruits, the main changes in the ripening of oil palm fruits are basically associated with the accumulation and increase of storage oil in the form of oil bodies in both storage tissues, i.e. the mesocarp and kernel (Sambanthamurthi et al., 2000). Being classified as a climacteric fruit (Tranbarger et al., 2011; Nurniwalis, 2017), the ripening-related gene expression of EGER D3 is likely the consequence of increased ethylene production in the ripening mesocarp tissues, indicating the important role of EGER D3 in oil palm fruit ripening. In addition, the expression of EGER D3, similar to that of oil synthesis in the mesocarp, suggests the possible involvement of ethylene in the accumulation of storage oils in mesocarp tissues.

In fruits like tomato, the ripening-related evidence to show that ethylene is required for climacteric fruit ripening was through the identification of an ethylene receptor $n r$ mutant

(A)

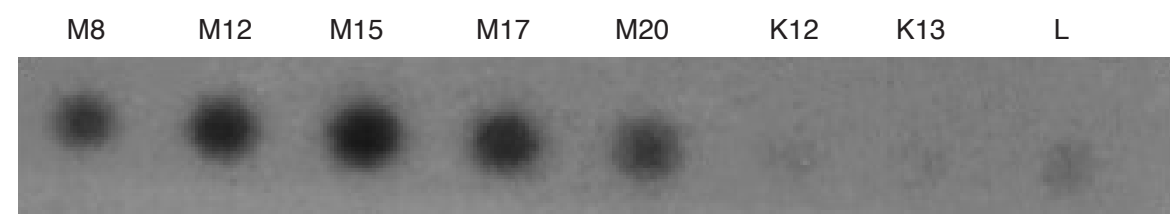

(B)

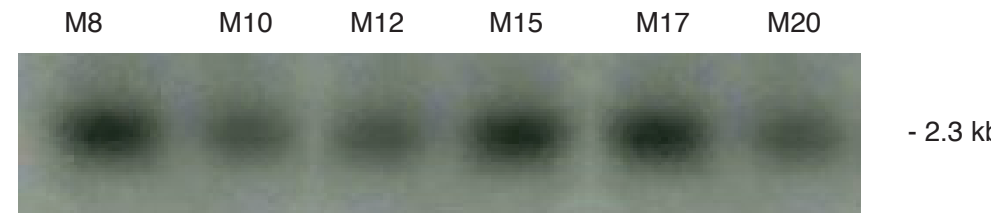

(C)

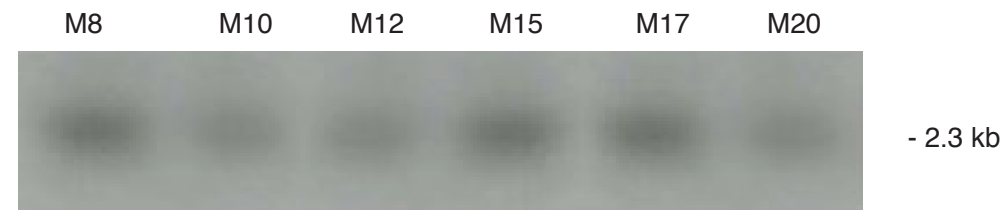

(D)

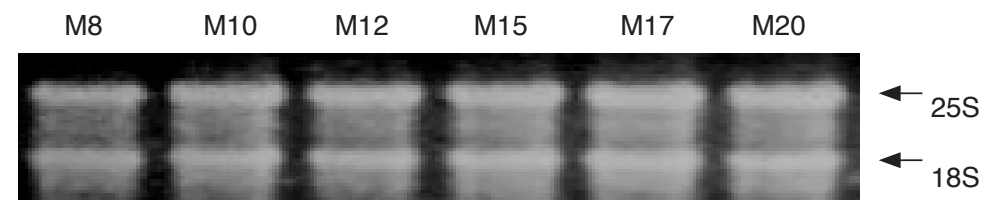

Figure 6. Gene expression analyses of the partial (A), full-length (B), and 3'UTR (C) EGER D3 ethylene receptor via Dot blot (A) and northern blot $(B$ and $C$ ) analyses. $D=$ ethidium bromide stained gel to show approximate loading of total $R N A$. $M=$ mesocarp, $K=k e r n e l, L=$ spear leaves. Numbers represent fruit developmental stages at weeks after anthesis (WAA). 
(Wilkinson et al., 1995). The $n r$ mutant has a specific point mutation within the ethylene-binding domain, eliminating its ability to bind ethylene which resulted in a tomato plant that has dominant insensitivity to ethylene and produced non-ripening fruits (Wilkinson et al., 1995). Characterisation of the role of ethylene receptors in many plants especially Arabidopsis and tomato have also demonstrated how plants regulate their ethylene sensitivity (Agarwal et al., 2012; Chang, 2016). Thus, this information have allowed the use of biotechnology tools to alter ethylene action in plants for crop improvement (Agarwal et al., 2012). For example, overexpression and suppression of ethylene receptor genes have produced transgenic crops with altered phenotypes, senescence and ripening (Agarwal et al., 2012). Antisense suppression of the tomato ethylene receptor NR gene in tomato $n r$ mutants restores normal ethylene sensitivity and produced fruits that ripen normally (Hackett et al., 2000; Tieman et al., 2000). On the other hand, when ethylene receptor LeETR4 was inserted into tomato via antisense and RNAi, down regulation of LeETR4 produced transgenic tomatoes that are extremely sensitive to ethylene which results in early fruit ripening (Tieman et al., 2000; Kevany et al., 2008). The possibility of manipulating ethylene receptors to control ethylene sensitivity in oil palm can therefore be looked into as a mean to understand processes related to oil palm fruit ripening such as the unsynchronised ripening of oil palm fruits within the fruit bunch, which may be of value to help further improve oil palm yields.

\section{CONCLUSION}

In conclusion, we have successfully isolated and characterised the first member of the ethylene receptor gene family from oil palm. EGER D3 contains conserved amino acid residues important to bind ethylene indicating the possibility of EGER D3 to function just like other normal ethylene receptors. Gene expression studies showed that the expression of EGER D3 was regulated throughout oil palm fruit development until ripening. The findings from this work clearly paves the way to explore further on the roles of ethylene in regulating the many developmental processes in oil palm, especially on fruit development and ripening processes.

\section{ACKNOWLEDGEMENT}

We thank the Director-General of MPOB for permission to publish this article. We would also like to thank Aminah Shuib and all the staff in the Gene Function Laboratory, MPOB for their technical help and assistance.

\section{REFERENCES}

ABELES, F B; MORGAN, P W and SALTVEIT, M E J (1992). Ethylene in Plant Biology. San Diego, CA, Academic.

AGARWAL, G; CHOUDHARY, D; SINGH, V P and ARORA, A (2012). Role of ethylene receptors during senescence and ripening in horticultural crops. Plant Signal. Behav., 7(7): 827-846.

ARAVIND, L and PONTING, C P (1997). The GAF domain: An evolutionary link between diverse phototransducing proteins. Trends Biochem Sci., 22: 458-459.

BINDER, B M; RODRÍGUEZ, F I and BLEECKER, A B (2010). The copper transporter RAN1 is essential for biogenesis of ethylene receptors in Arabidopsis. J. Biol. Chem., 285(48): 37263-37270.

BOUZAYEN, M; ALAIN, L; PAVENDRA, N and PECH, J-C (2010). Mechanism of fruit ripening. Plant Developmental Biology - Biotechnological Perspectives (Pua, E C and Davey, M eds.). Vol. 1, Heidelberg, Germany: Springer-Verlag. p. 319-339.

CHANG, C (2016). Q\&A: How do plants respond to ethylene and what is its importance? BMC Biology, 14: 7. DOI:10.1186/s12915-016-0230-0.

CHANG, C; KWOK, S F; BLEECKER, A B and MEYEROWITZ, E M (1993). Arabidopsis ethylene response gene ETR1: Similarity of product to twocomponent regulators. Science, 262: 539-544.

CORLEY, R H V and TINKER, P B (2016). The Oil Palm. Fifth edition. Oxford, UK: Wiley Blackwell Ltd.

DOYLE, J J and DOYLE, J L (1990). Isolation of DNA from small amounts of plant tissues. FOCUS, 12(1): 13-15.

GAMBLE, R L; COONFIELD, M L and SCHALLER, G E (1998). Histidine kinase activity of the ETR1 ethylene receptor from Arabidopsis. P Nat. Acad. Sci. USA, 95: 7825-7829.

GAO, Z; WEN, C K; BINDER, B M; CHEN, Y F; CHANG, J; CHIANG, Y H; KERRIS, R J; CHANG, $C$ and SCHALLER, G E (2008). Heteromeric interactions among ethylene receptors mediate signaling in Arabidopsis. J. Biol. Chem., 283: 2380123810.

HACKETT, R M; CHIN-WEN, H O; LIN, Z; FOOTE, H C C; FRAY, R G and GRIERSON, D (2000). Antisense inhibition of the $\mathrm{Nr}$ gene restores normal 
ripening to the tomato never-ripe mutant, consistent with the ethylene receptor-inhibition model. Plant Physiol., 124: 1079-1085.

HALL, A E; FINDELL, J L; SCHALLER, G E; SISLER, E C and BLEECKER, A B (2000). Ethylene perception by the ERS1 protein in Arabidopsis. Plant Physiol., 123(4): 1449-1458.

HENDERSON, J and OSBORNE, D J (1999). Ethylene as the initiator of the inter-tissue signalling and gene expression cascades in ripening and abscission of oil palm fruit. Biology and Biotechnology of the Plant Hormone Ethylene II (Kanellis, A K ed.). Doedrecht, Netherlands: Kluwer Academic Publishers. p. 129136.

HUA, J; SAKAI, H; NOURIZADEH, S; CHEN, Q G; BLEECKER, A B; ECKER, J R and MEYEROWITZ, E M (1998). EIN4 and ERS2 are members of the putative ethylene receptor gene family in Arabidopsis. Plant Cell, 10: 1321-1332.

HUNT, A G (2011). RNA regulatory elements and polyadenylation in plants. Frontiers in Plant Science, 2: 109. DOI:/ 10.3389/fpls.2011.00109.

IRELAND, H S; GUILLEN, F; BOWEN, J; TACKEN, E J; PUTTERILL, J; SCHAFFER, R J and JOHNSTON, J W (2012). Mining the apple genome reveals a family of nine ethylene receptor genes. Postharvest Biology and Technol., 72: 42-46.

KEVANY, B M; TAYLOR, M G and KLEE, H J (2008). Fruit-specific suppression of the ethylene receptor LeETR4 results in early-ripening tomato fruit. Plant Biotech. J. 6(3): 295-300.

KLEE, $\mathrm{H}$ and TIEMAN, D (2002). The tomato ethylene receptor gene family: Form and function. Plant Physiol., 115(3): 36-341.

KOZAK, M (1999). Initiation of translation in prokaryotes and eukaryotes. Gene, 234: 187-208.

MARCHLER-BAUER, A; BO, Y; HAN, L; HE, J; LANCZYCKI, CJ; LU, S; CHITSAZ, F; DERBYSHIRE, M K; GEER, R C; GONZALES, N R; GWADZ, M; HURWITZ, D I; LU, F; MARCHLER, G H; SONG, J S; THANKI, N; WANG, Z; YAMASHITA, R A; ZHANG, D; ZHENG, C; GEER, L Y and BRYANT, $S$ $H$ (2017). CDD/SPARCLE: functional classification of proteins via subfamily domain architectures. Nucleic Acids Res., 45(D): 200-203.

MASCHER, T; HELMANN, J D and UNDEN, G (2006). Stimulus perception in bacterial signaltransducing histidine kinases. Microbiol. Mol. Biol. Rev., 70(4): 910-938.
MCATEE, P; KARIM, S; SCHAFFER, $\mathrm{R}$ and DAVID, K (2013). A dynamic interplay between phytohormones is required for fruit development, maturation and ripening. Frontiers in Plant Sci., 4: 79.

NURNIWALIS, A W (2017). Physiological, Biochemical and Molecular Analyses of Fruit Development in Oil Palm (Elaeis guineensis Jacq.) Ph.D thesis, University of Nottingham Malaysia Campus, Malaysia.

NURNIWALIS, A W; ZUBAIDAH, R; SITI NOR AKMAR, A; ZULKIFLI, H; MOHAMAD ARIF, A M; MASSAWE, F J; CHAN, K L and PARVEEZ, G K A (2015). Genomic structure and characterization of a lipase class 3 gene and promoter from oil palm. Biologia Plantarum, 59(2): 227-236.

NURNIWALIS, A W; SUHAIMI, N; SITI NOR AKMAR, A; AMINAH, $S$ and MOHAMAD ARIF, M A (2008). Gene discovery via expressed sequence tags from the oil palm (Elaeis guineensis Jacq.) mesocarp. J. Oil Palm Res. Special Issue 2: 87-96.

NURNIWALIS, A W (2006). Isolation of Ethylene Response Sensor Gene and Generation of Expressed Sequence Tags from the Oil Palm (Elaeis guineensis Jacq.) Mesocarp. M.Sc. thesis, Universiti Putra Malaysia.

RASORI, A; RUPERTI, B; BONGHI, C; TONUTTI, $P$ and RAMINA, A (2002). Characterization of two putative ethylene receptor genes expressed during peach fruit development and abscission. J. Exp. Bot., 53: 2333-2339.

RODRIGUEZ, F; ESCH, J; HALL, A; BINDER, B; SCHALLER, E and BLEECKER, A (1999). A copper cofactor for the ethylene receptor ETR1 from Arabidopsis. Science, 283: 996-998.

SAMBANTHAMURTHI, R; SUNDRAM, $\mathrm{K}$ and TAN, Y (2000). Chemistry and biochemistry of palm oil. Prog. Lipid Res., 39: 507-558.

SAMBROOK, J and RUSSELL, D W (2001). Molecular Cloning: A Laboratory Manual. New York: Cold Spring Harbor Laboratory Press, New York, USA.

SATO-NARA, K; YUHASHI, K I; HIGASHI, K; HOSOYA, K; KUBOTA, M and EZURA, H (1999). Stage- and tissue-specific expression of ethylene receptor homolog genes during fruit development in muskmelon. Plant Physiol., 120: 321-330.

SCHALLER, G E and BLEECKER, A B (1995). Ethylene-binding sites generated in yeast expressing the Arabidopsis ETR1 gene. Science, 270: 1809-1811. 
TAKAHASHI, H; KOBAYASHI, T; SATO-NARA, K; TOMITA, K and EZURA, H (2002). Detection of ethylene receptor protein Cm-ERS1 during fruit development in melon (Cucumis melo L.). J. Exp. Bot., 53: 415-422.

TEH, H F; NEOH, B K; WONG, Y C; KWONG, Q B; OOI, T E K; NG, T L M; TIONG, S H; LOW, J Y S; DANIAL,AD;ERSAD, MA; KULAVEERASINGAM, $\mathrm{H}$ and APPLETON, D R (2014). Hormones, polyamines, and cell wall metabolism during oil palm fruit mesocarp development and ripening. $J$. Agric. Food Chem., 62: 8143-8152.

TERAJIMA, Y; NUKUI, $\mathrm{H}$; KOBAYASHI, A; FUJIMOTO, S; HASE, S; YOSHIOKA, T; HASHIBA, $\mathrm{T}$ and SATOH, S (2001). Molecular cloning and characterization of a cDNA for a novel ethylene receptor, NT-ERS1, of tobacco (Nicotiana tabacum L.). Plant and Cell Physiol., 42: 308-313.

THONGKUM, M; BURNS, P; BHUNCHOTH, B; WARIN, $\mathrm{N}$; CHATCHAWANKANPHANICH, O and VAN DOORND, W G (2009). Ethylene and pollination decrease transcript abundance of an ethylene receptor gene in Dendrobium petals. Plant Physiol., 176: 96-100.

TIEMAN, D M; TAYLOR, M G; CIARDI, J A and KLEE, H J (2000). The tomato ethylene receptors NR and LeETR4 are negative regulators of ethylene response and exhibit functional compensation within a multigene family. Proc. Natl. Acad. Sci. USA, 97: 5663-5668

TRANBARGER, T J; DUSSERT, S; JOET, T; ARGOUT, X; SUMMO, M; CHAMPION, A; CROS, D; OMORE, A; NOUY, B and MORCILLO, F (2011). Regulatory mechanisms underlying oil palm fruit mesocarp maturation, ripening, and functional specialization in lipid and carotenoid metabolism. Plant Physio., 156: 564-584.

WILKINSON, J; LANAHAN, M; YEN, H; GIOVANNONI, J and KLEE, H (1995). An ethyleneinducible component of signal transduction encoded by never-ripe. Science, 270: 1807-1809.

XIE, C; ZHANG, J; SLZHOU, H; LL LI, J; ZHANG, Z G: WANG, D W and CHEN, S Y (2003). Serine/ threonine kinase activity in the putative histidine kinase-like ethylene receptor NTHK1 from tobacco. Plant J., 33: 385-393.

YAU, C P; WANG, L; YU, M; ZEE, S Y and YIP, W K (2004). Differential expression of three genes encoding an ethylene receptor in rice during development, and in response to indole-3-acetic acid and silver ions. J. Exp. Bot., 55: 547-556.

ZHANG, Z G; ZHOU, H L; CHEN, T; GONG, Y; CAO, W H; WANG, Y J; ZHANG, J S and CHEN, S Y (2004). Evidence for serine/threonine and histidine kinase activity in the tobacco ethylene receptor protein NTHK2. Plant Physiol., 136: 2971-2981. 